\title{
Lipase production by solid-state fermentation of olive pomace in tray-type and pressurized bioreactors
}

\author{
Felisbela Oliveira, ${ }^{a}$ José Manuel Salgado, ${ }^{a}$ Noelia Pérez-Rodríguez, ${ }^{b, c}$ \\ José Manuel Domínguez, ${ }^{\mathrm{b}, \mathrm{c}}$ Armando Venâncio ${ }^{\mathrm{a}}$ and Isabel Belo ${ }^{a^{*}}{ }_{\odot}$
}

\begin{abstract}
BACKGROUND: Bioreactor type, sterilization and specific operational conditions are key factors for the scale-up of solid-state fermentation (SSF). This work deals with the lipase production by SSF of olive pomace (OP) in traditional tray-type and pressurized bioreactors. Important aspects of SSF in bioreactors were studied, such as the need for sterilization and moisture content (MC) control.

RESULTS: At larger scale, there was no significant difference in lipase production between sterilized and unsterilized substrates, but MC control had significant impact. The production of lipase in a pressurized bioreactor, under air absolute pressure of $200 \mathrm{kPa}$ and $400 \mathrm{kPa}$, was 2-fold higher than in a tray-type bioreactor using the same amount of substrate (500 g) and the same bed height. The protein content of substrate increased from 10 to $18 \%(\mathrm{w} / \mathrm{w})$ after SSF and the fermented solid presented an antioxidant activity of $10 \mathrm{mmol}$ Trolox $\mathrm{kg}^{-1}$.
\end{abstract}

CONCLUSIONS: SSF in a pressurized bioreactor enabled efficient production of lipase with higher substrate bed height in contrast to that in a tray-type bioreactor. The improvement in nutritional value of the substrate by SSF indicates its potential applicability in animal feed.

(c) 2017 Society of Chemical Industry

Keywords: solid-state fermentation; olive pomace; lipase production; tray-type bioreactor; pressurized bioreactor

\section{INTRODUCTION}

Solid-state fermentation (SSF) is defined as a fermentation process involving a moistened solid substrate as a support for growth and metabolism of microorganisms. ${ }^{1,2}$ SSF simulates the natural habitat of microorganisms grown on moist substrates, while submerged fermentation (SmF) can be considered as a change in their natural habitat, especially for filamentous fungi. ${ }^{1}$ The sterilization of substrate is a challenge in the scale-up of SSF to industrial development. The difficulty of filling the bioreactors with solid substrate in sterile conditions makes it essential to use sterile-in-place bioreactors, which increases the process costs (technology, time and energy consumption). Due to low water activity in SSF, sometimes the sterilization may not be needed. ${ }^{2}$ On the other hand, SSF offers the opportunity of using low cost agro-industrial residues for metabolite production. ${ }^{1}$

One such low cost residue is olive pomace (OP). OP is a sludgy waste generated by the two-phase extraction system of olive oil. It is an acidic and very moist material (74\% (w/w), wet basis), rich in organic matter, it contains water-soluble carbohydrates, phenols and residual olive oil, ${ }^{3}$ offering an excellent source of nutrients to produce lipases, since the remaining oil induces its production by microorganisms. In fact, previous work has demonstrated the ability of Aspergillus ibericus MUM 03.49 to produce lipase ${ }^{4}$ by SSF of OP with wheat bran (WB), and by SmF of olive mill wastewaters. ${ }^{5}$ The demand for lipases is increasing and its market was projected to reach $\$ 590.5$ million by $2020 .^{6}$ Lipases have many applications as additives in the food industry, fine chemicals, detergents, wastewater treatment, cosmetics, pharmaceuticals, leather processing and biomedical assays. ${ }^{7}$

In SSF processes at industrial level, the growth of microorganism and the production of metabolites may be limited by heat, nutrients and oxygen transfer. The design of bioreactor can help to reduce these limitations. ${ }^{8}$ Different bioreactor types have been used in SSF, including tray-type, packed-bed and horizontal rotary-drum, each one having advantages and disadvantages. ${ }^{2} \mathrm{~A}$ tray-type bioreactor consists of a chamber in which air, with controlled temperature and relative humidity, circulates around the trays. Each tray contains a thin layer of substrate, and usually has an open top and a perforated bottom. In addition, the relative humidity should be high to avoid the drying of the bed surface. ${ }^{8}$

\footnotetext{
Correspondence to: I Belo, CEB - Centre of Biological Engineering, University of Minho, Campus de Gualtar, 4710-057 Braga, Portugal.

E-mail: ibelo@deb.uminho.pt

a CEB - Centre of Biological Engineering, University of Minho, Braga, Portugal

b Department of Chemical Engineering, University of Vigo, Ourense, Spain

c Laboratory of Agro-food Biotechnology, CITI (University of Vigo)-Tecnópole, Ourense, Spain
} 
If fermentations are undertaken in trays with increasing bed thickness, the mass and energy transfer become more difficult. In this sense, the metabolic heat produced during the fermentation process is accumulated in the substrate bed, and the difficulty of transferring the heat from the centre of the bed can create gradients of temperature. ${ }^{9}$ Furthermore, the mycelium growth during the fermentation period accumulates in the substrate bed, filling up void spaces between particles, hindering the diffusion of air inside the substrate. ${ }^{9}$ Scale-up may be achieved by increasing the area of the trays, using wider trays, or simply using more trays. ${ }^{10}$ To avoid/or decrease drying of the substrate bed in SSF performed in a tray-type bioreactor, the substrate bed height and moist air supply must be considered. ${ }^{11}$

In rotary-drum bioreactors, rotation is applied to improve mass and heat transfer; however, the shearing forces may disrupt fungus mycelium. ${ }^{12}$ A pressurized bioreactor may overcome some of the previous problems, since the increased air pressure improves the oxygen transfer rate from air to aerobic cultures, increasing oxygen solubility in the media. ${ }^{13}$ This presents important operating cost savings in power consumption, that compensates the additional capital cost investment of the pressurized bioreactor. ${ }^{14,15}$ The pressurized bioreactor is typically a tank bioreactor already used in industry, such as in chemical processes, and may be constructed at several scales. However, there are limits for application of increased air pressure and consequently of increased oxygen partial pressure, since above certain values toxic effects on cell activity and product formation may occur. ${ }^{16}$ Increased air pressure has been successfully used in SmF, as reported by Lopes et al., ${ }^{17,18}$ who obtained significant improvements in lipase productivity by Yarrowia lipolytica under SmF, using air pressure up to $600 \mathrm{kPa}$. The use of continuous pressurized aeration in SSF has not been reported; however, pulse air pressure increases have been used to enhance mass and heat transfer in SSF, stimulating the growth and metabolism of microorganisms, ${ }^{19}$ as well as the production of different enzymes. ${ }^{20-23}$

SSF of agro-industrial residues is a promising alternative to improve the nutritional value of these by-products, allowing its use for animal feed. ${ }^{24}$ In addition to producing enzymes such as lipases, the fungus growth may increase protein content of the residues; it may increase the biodegradability facilitating the digestibility by ruminant animals; and it may reduce the content of polyphenols, which can affect the palatability of the residues. ${ }^{25}$ In this way, all fractions after SSF can be exploited by agro-food industries.

The aim of this work was to valorize OP by SSF to produce lipase using a traditional tray-type bioreactor and a novel pressurized bioreactor. Different aspects were evaluated such as the need for sterilization, moisture content (MC) control, the substrate bed height and the air pressure and aeration rate. In addition, the fermented substrate was characterized to evaluate its potential applicability for animal feed.

\section{MATERIAL AND METHODS \\ Biological material and substrates}

Aspergillus ibericus MUM 03.49 (MUM culture collection, Braga, Portugal) is a black Aspergillus, isolated from wine grapes. ${ }^{26}$ The fungus was grown on malt extract agar (MEA) plates $\left(20 \mathrm{~g} \mathrm{~L}^{-1}\right.$ malt extract, $20 \mathrm{~g} \mathrm{~L}^{-1}$ glucose, $1 \mathrm{~g} \mathrm{~L}^{-1}$ peptone and $20 \mathrm{~g} \mathrm{~L}^{-1}$ agar) at $30^{\circ} \mathrm{C}$ for 7 days and stored at $4^{\circ} \mathrm{C}$. Spore suspension of the inoculum was prepared by adding peptone solution $\left(1 \mathrm{~g} \mathrm{~L}^{-1}\right.$ and $0.1 \mathrm{~g} \mathrm{~L}^{-1}$ Tween 80) to plate cultures. The spore concentration of the suspension was adjusted to $10^{7}$ spores $\mathrm{mL}^{-1}$. OP samples were collected from a two-phase extraction system at an olive mill plant in Vila Real, Portugal, and stored at $-20^{\circ} \mathrm{C}$. Wheat bran (WB) was purchased in a local supermarket. Substrates were used without any pre-treatment.

\section{SSF of olive pomace with wheat bran}

SSF in flasks

SSF experiments were performed using OP mixed with $\mathrm{WB}$, in a ratio of 1:1 (w/w, dry basis), $0.0133 \mathrm{~g}$ of $\left(\mathrm{NH}_{4}\right)_{2} \mathrm{SO}_{4}$ per gram of dry solid substrate, $33.33 \mu \mathrm{L} \mathrm{g}^{-1}$ of inoculum solution with $10^{7}$ spores $\mathrm{mL}^{-1} .^{27}$ The mixture of OP with WB resulted in optimum MC, of around $60 \%(\mathrm{w} / \mathrm{w})$, without the need for its adjustment. Fermentations were carried out at $30^{\circ} \mathrm{C}$ in an incubator for 7 days without agitation..$^{4,27} \mathrm{SSF}$ were performed using sterilized $\left(121^{\circ} \mathrm{C}\right.$, $200 \mathrm{kPa}$ for $15 \mathrm{~min}$ ) and unsterilized substrate.

SSFs in cotton-plugged $500 \mathrm{~mL}$ Erlenmeyer flasks were performed using $30 \mathrm{~g}$ of dry solid substrate. SSFs were performed in triplicate, for experiments with and without sterilization. To visually compare the microorganism growth, a SSF control experiment using unsterilized and non-inoculated substrate was performed.

\section{SSF in tray-type bioreactor}

The tray-type bioreactor used consisted of an incubator $(112 \times 48 \times 45 \mathrm{~cm}) \quad($ FOC $225 \mathrm{E}$ Velp Scientifica, Usmate Velate $\mathrm{MB}$, Italia) containing four (non-perforated) stainless steel trays $(38 \times 26 \times 5 \mathrm{~cm})$. SSFs were performed using sterilized and unsterilized substrate, in quadruplicate. Substrate was sterilized in covered glasses and the incubator and trays were sterilized with $76 \%(\mathrm{v} / \mathrm{v})$ ethanol, before inoculation. Each tray was filled with $300 \mathrm{~g}$ of dry solid substrate and inoculated, resulting in a substrate bed height of $2.5 \mathrm{~cm}$. In SSF with MC control, MC was adjusted by adding sterile distilled water, once a day.

Another SSF was performed using $500 \mathrm{~g}$ of dry solid substrate in (non-perforated) smaller trays $(20 \times 25 \times 10 \mathrm{~cm})$, and covered with a polymeric (polyethylene) film, to avoid MC reduction. The substrate was not sterilized, and it was inoculated. A substrate bed height of $8 \mathrm{~cm}$ was obtained. Temperature of the substrate bed was monitored in all experiments.

\section{SSF in pressurized bioreactor}

SSFs were carried out in a $19 \mathrm{~L}$ ( $42 \mathrm{~cm}$ height and $24 \mathrm{~cm}$ diameter) pressurized bioreactor (4555, Parr Instrument Company, USA). SSFs were performed using $500 \mathrm{~g}$ of dry solid unsterilized substrate, with bed height of $8 \mathrm{~cm}$. Continuous absolute air pressures of $200 \mathrm{kPa}, 400 \mathrm{kPa}$ and $700 \mathrm{kPa}$ were selected by the inlet air pressure setting and by controlling the regulatory inlet and outlet air valves. Air was continuously sparged in the substrate bed at the bottom of the bioreactor, at aeration rates of $1 \mathrm{~L} \mathrm{~min}{ }^{-1}$ and $2 \mathrm{~L} \mathrm{~min}{ }^{-1}$, measured at the outlet gas conditions. Fermentation temperature was performed at $30^{\circ} \mathrm{C}$, using a thermostatic bath connected to a serpentine inside the pressurized bioreactor. SSF experiments were performed in duplicate.

\section{Enzyme extraction after SSF}

Fermented substrate was mixed with extracting solution composed of $10 \mathrm{~g} \mathrm{~L}^{-1}$ Triton X-100 in the proportion $5 \mathrm{~mL}$ per gram of dry solid substrate and incubated at $170 \mathrm{rpm}$ and $20^{\circ} \mathrm{C}$ for $2 \mathrm{~h}$. The whole fermented substrate from flasks and pressurized bioreactor were used for the extraction; in the tray-type bioreactor the substrate was divided into six equal parts and each part was used as a 
Table 1. Characteristics of olive pomace (OP), wheat bran (WB) and fermented substrate (SSF OP+WB). Values are the mean of triplicate analyses \pm standard deviation (SD)

\begin{tabular}{|c|c|c|c|c|}
\hline \multirow[b]{2}{*}{ Characteristic } & \multicolumn{4}{|c|}{ Value $\pm S D$} \\
\hline & OP & WB & $\mathrm{OP}+\mathrm{WB}$ & $\mathrm{SSF}(\mathrm{OP}+\mathrm{WB})$ \\
\hline $\mathrm{MC}(\%, \mathrm{w} / \mathrm{w})$ & $73.5 \pm 0.4$ & $12.5 \pm 0.1$ & $58.2 \pm 0.3$ & $65 \pm 2$ \\
\hline Total solids $(\%, w / w)$ & $26.5 \pm 0.4$ & $87.5 \pm 0.1$ & $41.8 \pm 0.3$ & $35 \pm 2$ \\
\hline Ash $\left(\mathrm{g} \mathrm{kg}^{-1}\right)$ & $66 \pm 5$ & $62.4 \pm 0.2$ & $64 \pm 3$ & $22.6 \pm 0.8$ \\
\hline $\operatorname{Lignin}\left(\mathrm{g} \mathrm{kg}^{-1}\right)$ & $432 \pm 5$ & $29.7 \pm 0.5$ & $231 \pm 3$ & $332 \pm 11$ \\
\hline Hemicellulose $\left(\mathrm{g} \mathrm{kg}^{-1}\right)$ & $223 \pm 8$ & $285 \pm 8$ & $254 \pm 4$ & $232 \pm 1$ \\
\hline Cellulose $\left(\mathrm{g} \mathrm{kg}^{-1}\right)$ & $125 \pm 9$ & $290 \pm 3$ & $208 \pm 6$ & $160 \pm 4$ \\
\hline Lipids $\left(\mathrm{g} \mathrm{kg}^{-1}\right)$ & $167 \pm 1$ & $36.6 \pm 0.4$ & $102 \pm 1$ & $24 \pm 3$ \\
\hline Protein $\left(\mathrm{g} \mathrm{kg}^{-1}\right)$ & $4 \pm 1$ & $8.6 \pm 0.2$ & $6 \pm 1$ & $1.5 \pm 0.3$ \\
\hline Reducing sugars $\left(\mathrm{g} \mathrm{kg}^{-1}\right)$ & $96 \pm 6$ & $15 \pm 2$ & $56 \pm 4$ & $17 \pm 2$ \\
\hline Phenols in water extract $\left(\mathrm{g} \mathrm{kg}^{-1}\right)$ & $8.4 \pm 0.3$ & $3.8 \pm 0.3$ & $6.1 \pm 0.3$ & $4.9 \pm 0.7$ \\
\hline Phenols in $\mathrm{MeOH}$ extract $\left(\mathrm{g} \mathrm{kg}^{-1}\right)$ & $11 \pm 0.9$ & $5 \pm 0.1$ & $8 \pm 0.2$ & $5.8 \pm 0.6$ \\
\hline Antioxidant activity (mmol Trolox $\mathrm{kg}^{-1}$ ) & $55 \pm 0.3$ & $5.6 \pm 0.7$ & $30.6 \pm 1.9$ & $10.3 \pm 0.3$ \\
\hline Antioxidant activity $\left(\mathrm{IC}_{50}\right)$ & 1.25 & 18.2 & 2.6 & 8.1 \\
\hline $\mathrm{N}(\%, \mathrm{w} / \mathrm{w})$ & $0.6 \pm 0.1$ & $2.57 \pm 0.04$ & $1.6 \pm 0.1$ & $2.87 \pm 0.04$ \\
\hline$C(\%, w / w)$ & $49.7 \pm 0.7$ & $44.3 \pm 0.2$ & $47 \pm 0.5$ & $49.0 \pm 0.2$ \\
\hline $\mathrm{C} / \mathrm{N}$ ratio & $83 \pm 7$ & $17 \pm 5$ & $25 \pm 6$ & $17 \pm 5$ \\
\hline Crude protein $(\%, w / w)$ & $3.8 \pm 0.6$ & $16.1 \pm 0.3$ & $9.9 \pm 0.4$ & $17.9 \pm 0.3$ \\
\hline $\mathrm{Ca}\left(\mathrm{g} \mathrm{kg}^{-1}\right)$ & $1.16 \pm 0.04$ & $1.85 \pm 0.09$ & $1.51 \pm 0.07$ & $2.3 \pm 0.5$ \\
\hline$K\left(\mathrm{~g} \mathrm{~kg}^{-1}\right)$ & $17 \pm 1$ & $18 \pm 1$ & $18 \pm 1$ & $5.8 \pm 0.5$ \\
\hline$M g\left(g ~ k g^{-1}\right)$ & $0.474 \pm 0.22$ & $5.1 \pm 0.3$ & $2.8 \pm 0.3$ & $2.9 \pm 0.4$ \\
\hline $\mathrm{Zn}\left(\mathrm{mg} \mathrm{kg}^{-1}\right)$ & $12 \pm 0$ & $145 \pm 3$ & $79 \pm 2$ & $96 \pm 21$ \\
\hline $\mathrm{Cu}\left(\mathrm{mg} \mathrm{kg}^{-1}\right)$ & $11.5 \pm 0.7$ & $14 \pm 0$ & $12.8 \pm 0.4$ & $17 \pm 4$ \\
\hline $\mathrm{Fe}\left(\mathrm{mg} \mathrm{kg}^{-1}\right)$ & $42 \pm 2$ & $134 \pm 4$ & $88 \pm 3$ & $103 \pm 10$ \\
\hline $\mathrm{Mn}\left(\mathrm{mg} \mathrm{kg}^{-1}\right)$ & $8.6 \pm 0.1$ & $128.5 \pm 0.7$ & $68.6 \pm 0.4$ & $74 \pm 13$ \\
\hline $\mathrm{Cr}\left(\mathrm{mg} \mathrm{kg}^{-1}\right)$ & $<22$ & $<15$ & $<19$ & $<15$ \\
\hline $\mathrm{Ni}\left(\mathrm{mg} \mathrm{kg}^{-1}\right)$ & $<22$ & $<15$ & $<19$ & $<15$ \\
\hline $\mathrm{Pb}\left(\mathrm{mg} \mathrm{kg}^{-1}\right)$ & $<22$ & $<15$ & $<19$ & $<15$ \\
\hline $\mathrm{Na}\left(\mathrm{mg} \mathrm{kg}^{-1}\right)$ & $373 \pm 35$ & $96 \pm 1$ & $235 \pm 18$ & $116 \pm 17$ \\
\hline
\end{tabular}

sample. Enzymatic extracts were then centrifuged $(12000 \times g$ and 10 min at $4{ }^{\circ} \mathrm{C}$ ) and filtered. The resulting enzymatic extracts were immediately used for lipase determination.

\section{Analyses of enzymes and protein}

Lipase activity was determined by a spectrophotometric method, using $p$-nitrophenyl butyrate in potassium phosphate $50 \mathrm{mmol} \mathrm{L}^{-1}$ at $\mathrm{pH} 7.0$ and $37^{\circ} \mathrm{C}$ for $15 \mathrm{~min}$. The absorbance was measured at $405 \mathrm{~nm}$, as described by Oliveira et al. ${ }^{28} 1$ unit of lipase activity (U) was expressed as the amount of enzyme that produces $1 \mu \mathrm{mol}$ of $p$-nitrophenol per min, under the assay conditions. Lipase activity was expressed as units per gram of dry solid substrate $\left(\mathrm{U} \mathrm{g}^{-1}\right)$.

The protein content of the extract was determined by Bradford's method, using bovine serum albumin (BSA) as standard. ${ }^{29}$ Protein concentration was expressed as gram of protein per kilogram of dry solid substrate $\left(\mathrm{g} \mathrm{kg}^{-1}\right)$. Specific activity was obtained by the ratio between lipase activity and protein concentration. It was expressed as units of lipase activity per milligram of total protein $\left(\mathrm{U} \mathrm{mg}^{-1}\right)$. All analyses were performed in triplicate.

Other enzymes were determined in the enzymatic extract after 7 days of SSF using sterilized substrate. Xylanase, cellulase and $\beta$-glucosidase were determined through the methodology described by Salgado et al. ${ }^{25}$ Lignin peroxidase, manganese peroxidase and laccase were determined through the methodology described by Salgado et al. ${ }^{30}$ Enzyme activity was expressed as units per gram of dry solid substrate $\left(\mathrm{U} \mathrm{g}^{-1}\right)$.

\section{Characterization of substrates before and after SSF}

The composition of substrates before and after SSF was determined to evaluate the increase of nutritional quality and potential applicability for animal feed. Initial characterization of OP was performed by Leite et al. $^{31}$ and is presented in Table 1. Characteristics of WB and of fermented substrate (SSF OP + WB), such as MC, total solids, ash, lignin, hemicellulose, cellulose, lipids, protein concentration, reducing sugars, phenols, nitrogen, carbon, crude protein, minerals and heavy metals, were determined according to Leite et $a .^{31}$ and Salgado et al. ${ }^{25}$

The extracts for antioxidant determination in unfermented and fermented substrates were obtained by methanol extraction with liquid:solid ratio of 20:1 (v/w). The extraction was carried out in Pyrex bottles in an incubator shaker at $50^{\circ} \mathrm{C}, 100 \mathrm{rpm}$ and $1 \mathrm{~h}$, and the extracts were filtered. Antioxidant activity was determined by 2,2-diphenyl-1-picrylhydrazyl (DPPH) radical scavenging assay described by Dulf et al. ${ }^{32}$ Known amounts of 6-hydroxy-2,5,7,8-tetramethylchroman-2-carboxylic acid (Trolox) were used for calibration. The free radical scavenging activity of the extracts was expressed as millimoles of Trolox equivalent per kilogram of dry solid substrate $\left(\mathrm{mmol} \mathrm{kg}^{-1}\right)$, and as concentration of sample that reduces the DPPH radical scavenging activity at $50 \%$ $\left(\mathrm{IC}_{50}\right)$.

Since the ratio (dry basis) used in SSF was 1:1 (w/w), an average between the initial characteristics of OP and WB was determined, to observe modifications in the concentration of compounds after 
SSF. A characteristic increase (or reduction) in relation to the initial value was determined by the following equation:

$$
X I R=\left(X_{f}-X_{i}\right) / X_{i} \times 100
$$

where $X I R$ is a characteristic increase (or reduction) expressed in percentage (\%), $X_{i}$ is the initial value of a characteristic (before SSF), and $X_{f}$ is the final value of a characteristic (after 7 days of SSF).

\section{Analysis of experimental data}

The data obtained were analyzed statistically using SPSS (IBM SPSS Statistics, Version 22.0. Armonk, NY: IBM Corp.) to study the effect of variables on lipase production and its specific activity. Data were tested for homogeneity, submitted to one-way analysis of variance (ANOVA) and a pair-wise multiple comparison procedure (Tukey test), at a confidence level of $95 \%$.

\section{RESULTS AND DISCUSSION}

\section{Effect of sterilization on lipase production by SSF in flasks}

The evaluation of sterilization effect on lipase production was first carried out in Erlenmeyer flasks using sterilized and unsterilized inoculated substrates. A SSF control experiment was performed with unsterilized and non-inoculated substrate. The growth of A. ibericus was visually observed in both inoculated substrates. In the control assay, the growth of different autochthonous microorganisms producing different green and brown colonies was observed, unlike the black spots observed in flasks inoculated with $A$. ibericus. In this sense, the inoculation with $A$. ibericus allowed fast growth and avoidance of the proliferation of autochthonous microorganisms. In the olive ecosystems, different microorganisms can be found, such as yeasts, ${ }^{33}$ bacteria $^{34}$ and filamentous fungi. ${ }^{35}$ In particular, Baffi et al. ${ }^{35}$ isolated 14 species of fungi from olive ecosystems, belonging to seven different genera (Aspergillus, Penicillium, Rhizomucor, Mucor, Rhizopus, Lichtheimia and Galactomyces). However, only sterilization of the substrate can remove completely the wild microbial population, contributing to better colonization with Aspergillus strain used as inoculum.

Lipase production was higher in SSF using sterilized substrate (Fig. 1). In flasks using unsterilized substrate, lipase production and specific activity decreased by $34 \%$ and $40 \%$, respectively. On the other hand, in control experiment (unsterilized and non-inoculated) a lower lipase production was achieved. The sterilization and inoculation with $A$. ibericus spores on OP and WB mixture led to 2.7-fold increase in lipase production, compared with the control fermentation.

The positive effect of substrate sterilization in small-scale fermentations may be also due to the modification of the solid structure, which leads to the formation of micropores in the substrate, incrementing the specific surface area, ${ }^{36}$ and improving the water solubility and water binding properties. ${ }^{37}$ Consequently, the accessibility of the fungus and its enzymes to the micro and macronutrients of the substrate (OP + WB) may increase. For these reasons, sterilization step may be considered as a pre-treatment of substrate. In this sense, Pensupa et al. ${ }^{38}$ observed that the production of cellulases with substrate treated by autoclave and dilute acid was similar and improved the results compared with untreated substrate.

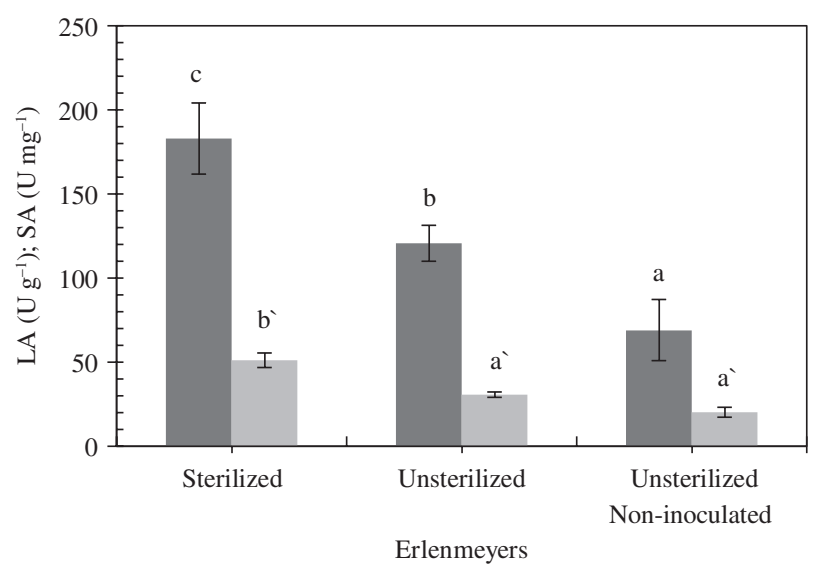

Figure 1. Results of ( $\square$ ) lipase activity (LA) and ( $\square$ ) specific activity (SA) of SSF in $500 \mathrm{~mL}$ Erlenmeyer flasks, using sterilized and unsterilized substrate, and using unsterilized and non-inoculated substrate. Depicted values are the mean of three independent fermentation experiments \pm standard deviation. Means with the same letter do not differ significantly at $P>0.05$ (Tukey test).

Table 2. Results of lipase activity (LA), specific activity (SA) and moisture content $(\mathrm{MC})$, from SSF in a tray-type bioreactor, with and without MC control, and using unsterilized and sterilized substrate. Values are themean of four trays \pm standard deviation (SD). Means with the same letter do not differ significantly at $P>0.05$ (Tukey test)

\begin{tabular}{|cccc|} 
SSF conditions & $\begin{array}{c}\mathrm{LA} \pm \mathrm{SD} \\
\left(\mathrm{U} \mathrm{g}^{-1}\right)\end{array}$ & $\begin{array}{c}\mathrm{SA} \pm \mathrm{SD} \\
\left(\mathrm{U} \mathrm{mg^{-1 }}\right)\end{array}$ & $\begin{array}{c}\mathrm{MC} \pm \mathrm{SD} \\
(\%, \mathrm{w} / \mathrm{w})\end{array}$ \\
\hline $\begin{array}{c}\text { Without MC control, } \\
\text { sterilized }\end{array}$ & $74 \pm 10^{\mathrm{a}}$ & $22 \pm 2^{\mathrm{a}}$ & $27 \pm 3^{\mathrm{a}}$ \\
$\begin{array}{l}\text { With MC control: } \\
\text { Sterilized substrate }\end{array}$ & $111 \pm 14^{\mathrm{b}}$ & $36 \pm 6^{\mathrm{b}}$ & $66 \pm 3^{\mathrm{b}}$ \\
$\begin{array}{l}\text { Unsterilized } \\
\text { substrate }\end{array}$ & $131 \pm 16^{\mathrm{b}}$ & $25 \pm 4^{\mathrm{a}}$ & $67 \pm 3^{\mathrm{b}}$ \\
\hline
\end{tabular}

\section{SSF in tray-type bioreactor}

SSF was performed in a tray-type bioreactor using $300 \mathrm{~g}$ of dry solid sterilized substrate, with and without MC control. In SSF without MC control, MC loss rate of the trays was higher in the first days of fermentation and decreased with time. After 7 days of fermentation (Table 2), lower lipase activity was obtained, since MC decreased by $55 \%$ (from $60 \%$ to $27 \%$ ). However, in SSF with MC control, higher lipase production was obtained, leading to $50 \%$ increase of lipase activity and $63 \%$ increase of specific activity. $\mathrm{MC}$ control minimizes the negative effects of low MC, such as the reduction in the solubility of nutrients of the substrate. ${ }^{39}$

The 10-fold scale increase of SSF from flasks to tray-type bioreactor with $\mathrm{MC}$ control in sterile conditions led to a significant decrease (40\%) in lipase production and $29 \%$ decrease of specific activity. This decrease could be caused by the slight dehydration of the substrate (an average of 10\% MC loss) during each day of SSF. Also, the accumulated heat inside the substrate bed, produced by fungus growth and metabolic activity, increases as the load substrate and/or bed height increases. This can lead to temperature increase and consequently to MC loss. In fact, the temperature in the tray-type bioreactor over the fermentation time increased from $30^{\circ} \mathrm{C}$ to $34.3^{\circ} \mathrm{C}$, after 1 day of fermentation. The increase of temperature above optimum level $\left(30^{\circ} \mathrm{C}\right)$ for lipase production by $A$. ibericus has a negative impact on final activity. ${ }^{4}$ 
(a)

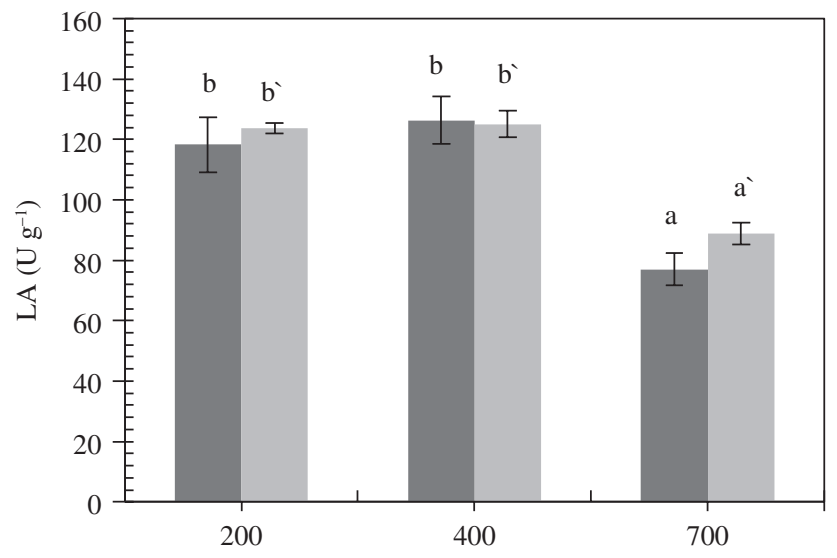

Absolute pressure $(\mathrm{kPa})$ (b)

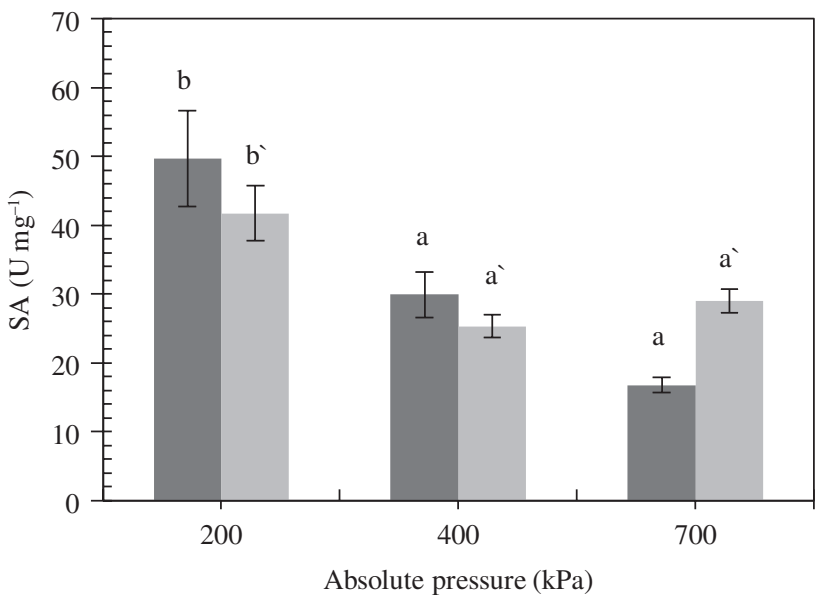

Figure 2. Results of (a) lipase activity (LA) and (b) specific activity (SA) of SSF of unsterilized substrate in a pressurized bioreactor at different absolute air pressures and at $(\square) 1 \mathrm{~L} \mathrm{~min}^{-1}$ and ( $2 \mathrm{~L} \mathrm{~min}^{-1}$ of aeration rate. Depicted values are the mean of two independent fermentation experiments \pm standard deviation. Means with the same letter do not differ significantly at $P>0.05$ (Tukey test).

In general, the increase of substrate bed height has significant negative impact in lipase production in a tray-type bioreactor. Edwinoliver et al. ${ }^{40}$ scaled-up the lipase production from flasks with $10 \mathrm{~g}$ of substrate to tray-type bioreactor with $100 \mathrm{~g}(0.8 \mathrm{~cm}$ substrate bed height) and $1 \mathrm{~kg}(1.5 \mathrm{~cm}$ substrate bed height), and reported a reduction of $4 \%$ and $17 \%$, respectively, in lipase produced by $A$. niger on WB, coconut oil cake and raw wheat. The decrease of lipase activity was attributed to the temperature increase during the culture growth. Vaseghi et al. ${ }^{9}$ reported an optimum substrate bed height of $0.5 \mathrm{~cm}$, in comparison with using $3 \mathrm{~cm}$, for SSF on sugarcane bagasse for Rhizopus oryzae lipase production in a tray-type bioreactor, yielding around $200 \mathrm{U} \mathrm{g}^{-1}$. The substrate bed height may be reduced by increasing the tray area, to prevent temperature gradients and maximizing lipase production. ${ }^{10}$

In SSF experiments with MC control using $300 \mathrm{~g}$ of substrate, no significant impact of substrate sterilization was observed (Table 2). Thus, at larger scale, the SSF process is feasible using substrate without pre-treatment, as autoclave sterilization, where the fungus A. ibericus can grow and produce lipase.

\section{SSF at pressurized bioreactor}

SSF process in a pressurized bioreactor was carried out with $500 \mathrm{~g}$ of unsterilized substrate. Figure 2 presents the results of SSF in the pressurized bioreactor, at aeration rates of $1 \mathrm{~L} \mathrm{~min}^{-1}$ and $2 \mathrm{~L}$ $\mathrm{min}^{-1}$, and at different absolute air pressures. Maximum lipase activity $\left(126 \pm 8 \mathrm{U} \mathrm{g}^{-1}\right.$ at $1 \mathrm{~L} \mathrm{~min}^{-1}$ and $\left.400 \mathrm{kPa}\right)$ was found at lower air pressures of $200 \mathrm{kPa}$ and $400 \mathrm{kPa}$, without statistical difference between these results. However, maximum specific activity was obtained at $200 \mathrm{kPa}$. Results of lipase and specific activities were similar at aeration rates of $1 \mathrm{~L} \mathrm{~min}^{-1}$ or $2 \mathrm{~L} \mathrm{~min}^{-1}$. Also, no significant differences in $\mathrm{MC}$ of fermented substrate at different conditions of air pressure and aeration rate were observed. Similarly, Oliveira et al. ${ }^{27}$ found equal lipase production by SSF in a packed-bed bioreactor, using $25 \mathrm{~g}$ of substrate, at aeration rates of 0.05 and $0.1 \mathrm{~L} \mathrm{~min}^{-1}$.

The results of lipase activity obtained in the pressurized bioreactor with unsterilized substrate, under $200 \mathrm{kPa}$ or $400 \mathrm{kPa}$ and $1 \mathrm{~L}$ $\mathrm{min}^{-1}$ or $2 \mathrm{~L} \mathrm{~min}{ }^{-1}$, were statistically similar to the lipase obtained in flasks with unsterilized substrate. However, about $60 \%$ significant increase was observed in specific activity, indicating that the pressure increase may be an important operating factor for optimization of enzyme production, since it may affect differently the expression of several enzymes.

Another SSF was performed in a tray-type bioreactor, using the same amount of substrate $(500 \mathrm{~g})$ and bed height of $8 \mathrm{~cm}$, to compare the results obtained in a pressurized bioreactor with that in a tray-type. Trays were covered with a perforated polymeric film to simulate the close environment as in the pressurized bioreactor. The coverage of the tray prevented MC loss. Lipase production in the tray-type using $500 \mathrm{~g}$ substrate yielded $61 \pm 13 \mathrm{U} \mathrm{g}^{-1}$, significantly lower (around 50\%) than all the values obtained under other conditions tested. This result may be attributed to the temperature rise inside the substrate bed that increased dramatically after 1 day of fermentation to around $36^{\circ} \mathrm{C}$. Moreover, mycelium growth was observed in all the substrate of the trays, but sporulation occurred only at the substrate surface, indicating oxygen limitations through the substrate bed.

Contrarily, in the pressurized bioreactor, fungus growth and sporulation were observed in all substrates, at all conditions tested. In aerobic cultures, total air pressure is a key controlling factor, as it alters the dissolved gas partial pressure, in particular, the dissolved oxygen, which may be a limiting factor for cell growth and metabolic activity. ${ }^{17}$ The effect of pressure on the microorganism metabolism depends on the culture conditions, pressurization mode and the microorganism itself. ${ }^{17}$ The continuous pressurized aeration in the bioreactor may allow efficient gas exchange over the fermentation time and the dissipation of excessive heat derived from fungus growth, even using a high substrate bed height. This proved that the use of a pressurized bioreactor may effectively maintain lipase production with high substrate bed height.

SSF under increased air pressure has been well explored and there is some work using air pressure pulsation instead of continuous air pressure, as was used in this work. Aijun et al. ${ }^{20}$ applied air pressure pulsation SSF, and found that the protease of Bacillus pumilus increased $63 \%$ and $95 \%$, in relation to static SSF, when pressure amplitude used was $50 \mathrm{kPa}$ and $100 \mathrm{kPa}$, respectively. This process supplied sufficient oxygen and enlarged the aerobic 
(a)

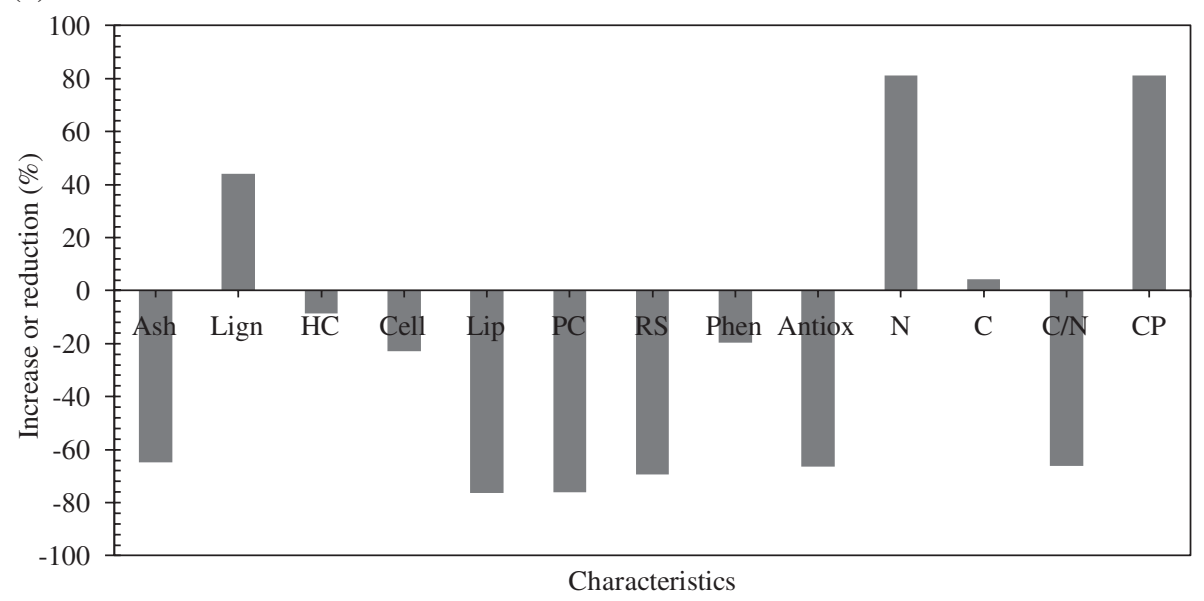

(b)

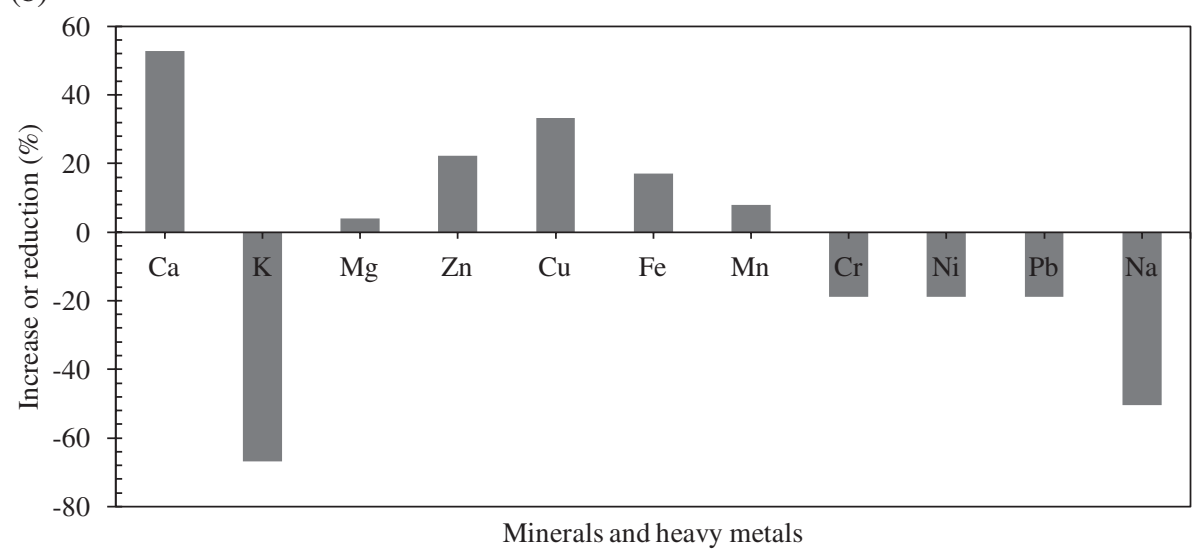

Figure 3. Increase (positive values) or reduction (negative values) of (a) the characteristics and (b) minerals and heavy metals of the fermented substrate, after 7 days of SSF using sterilized substrate.

surface for microorganism growth. ${ }^{20}$ Similarly, Zeng and Chen ${ }^{21}$ applied cycles of 20 min without pressure increase and 10 s pulses of air at $200 \mathrm{kPa}$ in SSF, and observed that feruloyl esterase production by $A$. niger improved and the fermentation time to achieve the highest enzyme production was shortened, compared with static SSF.

This work demonstrated that SSF under pressurized air could improve specific activity, being favorable to the enzyme purification step. However, when using higher pressures $(700 \mathrm{kPa})$ the lipase activity decreased, probably due to unbalanced oxidative stress. To our knowledge, this is the first report on the study of A. ibericus lipase production by an SSF process under continuous pressurized aeration conditions.

\section{Modifications in substrate composition after SSF}

The substrates (OP and WB) were analyzed before and after 7 days of SSF, to observe the nutritional composition modification. Table 1 presents the main chemical parameters of these substrates. Figure 3 presents the respective increase or reduction of the characteristics after SSF, in relation to the initial characteristic value of the substrate (mixture 1:1 of OP with WB).

The crude protein is an important parameter to consider in animal feed. Through SSF, the crude protein content increased by $81 \%$, reaching $18 \%(\mathrm{w} / \mathrm{w})$ in the dry solid fermented substrate. This increase is correlated with the biomass produced from fungal growth during SSF. The protein content in similar species to $A$. niger is estimated at $27 \%(\mathrm{w} / \mathrm{w}) .^{41}$ Results confirmed the efficacy of SSF to enhance the protein content of the fermented substrate. Moreover, the value of crude protein achieved in the fermented solid is within the range of protein used in animal feed. ${ }^{25}$ For example, basal broiler chicken diet includes a crude protein level of $18.5 \%$ during the first $7-8$ weeks and $16 \%$ for the subsequent 9-14 weeks. ${ }^{42}$ Similarly to this work, Li et $a . .^{42}$ obtained a crude protein increase of $80 \%$, using $A$. niger on SSF of solid wastes from Silybum marianum fruits. Salgado et al..$^{25}$ also observed an increase of $107 \%$ using $A$. uvarum by SSF using mixture of winery by-products and OP. Canedo et al. ${ }^{24}$ found a $100 \%$ increase in crude protein content after 7 days of SSF in the fermented wastes of brewery spent grain using Rhizopus oligosporus. The use of $A$. ibericus in SSF is safe as mycotoxins are not produced, ${ }^{26}$ it provides a protein concentrate, and may give an alternative use of the by-products from the olive mill industry as animal feed. After SSF, reductions of $9 \%$ and $23 \%$ in hemicellulose and cellulose, were observed (Fig. 3), respectively. Lignocellulolytic enzymes such as cellulases and xylanases, and the enzyme $\beta$-glucosidase were detected in the extracts at activities of $5.1 \pm 0.6 \mathrm{U} \mathrm{g}^{-1}, 9.1 \pm 0.5 \mathrm{U}$ $\mathrm{g}^{-1}$ and $48 \pm 1 \mathrm{U} \mathrm{g}^{-1}$, respectively. These enzymes caused slight degradation of hemicellulose and cellulose. These reductions may improve the digestibility and accessibility of these components in the digestive tract of animals. ${ }^{25}$ On the other hand, lignin was not consumed and the presence of ligninases as lignin peroxidase, 
laccase and manganese peroxidase, was not detected. Thus, the lignin relative proportion and concentration increased in the fermented substrate, compared with the unfermented one.

Phenolic compounds were reduced by $20 \%$ after 7 days of SSF by A. ibericus, even without the presence of laccases and peroxidases. Filamentous fungi are able to degrade phenolic compounds. ${ }^{43}$ In previous work, the same strain of $A$. ibericus was used in SmF of diluted olive mill wastewater, where reductions of $28 \%$ and $37 \%$ in phenolic compounds were observed. ${ }^{5}$ Similarly, Salgado et al. ${ }^{25}$ observed a reduction of $28 \%$ in phenolic compounds by $A$. uvarum after 10 days of SSF, using a mixture of winery by-products and OP. Reduction of phenolic compounds in the fermented substrate was positive, since they negatively affect the animal's feed intake, feed digestibility and production efficiency. ${ }^{25}$

The antioxidant activity of unfermented and fermented substrates was determined (Table 1). High antioxidant activity of extracts from OP and low antioxidant activity of extracts from WB before SSF were observed. After SSF, a reduction in antioxidant activity in fermented substrate was observed, due to the extraction of phenolic compounds during enzyme recovery. The antioxidant activity in enzymatic extracts was $14.2 \pm 1 \mathrm{mmol}^{\text {Trolox }} \mathrm{kg}^{-1}$; the sum of antioxidant activity in extract from fermented substrate and enzymatic extract was $24.5 \mathrm{mmol}$ Trolox $\mathrm{kg}^{-1}$. Thus, the antioxidant capacity was reduced after SSF. This may have been due to the reduction of phenolic compounds by fungus, as can be seen in methanolic extracts before and after SSF (Table 1). However, the antioxidant activity in fermented substrate maintained an interesting level, which was similar to the values of antioxidant activity in 112 medicinal plants. ${ }^{44}$

Lipids suffered a drastic reduction of $76 \%$, after 7 days of SSF. This was a result of SSF optimization for lipase production. A final lipids concentration of $2.4 \pm 0.3 \%$ was found. The concentration obtained is interesting for animal feed, since the lipids found in grains and forages naturally make up approximately $2-4 \%$ of the feed. ${ }^{45}$

Figure 3 presents the modifications in the percentage of minerals and heavy metals of the fermented substrate, in relation to the unfermented one. Highest reductions were found for potassium and sodium contents, and highest increases for calcium and copper. Results are in agreement with the literature for copper, zinc, manganese and iron increases..$^{25,46}$ Joshi and Sandhu ${ }^{46}$ reported increases in those minerals after SSF of WB using different yeast species, Saccharomyces, Candida and Torula. Also, Salgado et al. ${ }^{25}$ observed an increase of iron in the substrate by SSF of a mixture of winery by-products and OP using A. uvarum. The reduction of sodium was confirmed by Joshi and Sandhu ${ }^{46}$ and Salgado et al..$^{25}$ Contrary to the results presented, these authors found an increase in potassium and reduction in calcium and magnesium. ${ }^{25,46} \mathrm{An}$ increase in microelements (calcium, magnesium, zinc, copper, iron and manganese) by fermentation improved the nutritive value of OP with WB, with possible higher availability to livestock. In addition, reductions of heavy metals contents were observed (chromium, nickel and lead).

\section{CONCLUSIONS}

Sterilization of the substrate for SSF at small scale led to higher lipase production. However, it was proved that at large scale, the sterilization step is not necessary. SSF was successfully performed in a tray-type bioreactor but MC loss needs to be prevented. For the first time, SSF was successfully performed in a pressurized bioreactor for lipase production. SSF in this bioreactor seemed to be more effective than in the tray-type, improving specific lipase activity. This work presented an integrated waste valorization process using OP residue for lipase production and nutritional value increase of the fermented substrate.

\section{ACKNOWLEDGEMENTS}

Felisbela Oliveira acknowledges the financial support from the Portuguese Foundation for Science and Technology (FCT) through grant SFRH/BD/87953/2012. José Manuel Salgado was supported by grant CEB/N2020 - INV/01/2016 from Project "BIOTECNORTE - Underpinning Biotechnology to foster the north of Portugal bioeconomy" (NORTE-01-0145-FEDER-000004). This study was supported by the Portuguese Foundation for Science and Technology (FCT) under the scope of the strategic funding of UID/BIO/04469/2013 unit and COMPETE 2020 (POCl-01-0145-FEDER-006684) and BioTec-Norte operation (NORTE-01-0145-FEDER-000004) funded by the European Regional Development Fund under the scope of Norte2020 Programa Operacional Regional do Norte.

Noelia Pérez-Rodríguez acknowledges the financial support of FPU from Spanish Ministry of Education, Culture and Sports. The authors thank the Spanish Ministry of Science and Innovation for the financial support of this work (project CTQ2011-28967), which has partial financial support from the FEDER funds of the European Union.

\section{REFERENCES}

1 Pandey A, Solid-state fermentation. Biochem Eng J 13:81-84 (2003).

2 Singhania RR, Patel AK, Soccol CR and Pandey A, Recent advances in solid-state fermentation. Biochem Eng J 44:13-18 (2009).

3 Alburquerque JA, Gonzálvez J, García D and Cegarra J, Effects of bulking agent on the composting of 'alperujo', the solid by-product of the two-phase centrifugation method for olive oil extraction. Process Biochem 41:127-132 (2006).

4 Oliveira F, Moreira C, Salgado JM, Abrunhosa L, Venâncio A and Belo I, Olive pomace valorization by Aspergillus species: lipase production using solid-state fermentation. J Sci Food Agric 96:3583-3589 (2016).

5 Abrunhosa L, Oliveira F, Dantas D, Gonçalves C and Belo I, Lipase production by Aspergillus ibericus using olive mill wastewater. Bioprocess Biosyst Eng 36:285-291 (2013).

6 MarketsandMarkets. Lipase market worth $\$ 590.5$ million by 2020 . http://www.marketsandmarkets.com/PressReleases/lipase.asp [11 September 2017].

7 Salihu A, Alam MZ, AbdulKarim MI and Salleh HM, Lipase production: an insight in the utilization of renewable agricultural residues. Resource Conserv Recycl 58:36-44 (2012).

8 Mitchell DA, Krieger N, Stuart DM and Pandey A, New developments in solid-state fermentation II. Rational approaches to the design, operation and scale-up of bioreactors. Process Biochem 35:1211-1225 (2000).

9 Vaseghi Z, Najafpour GD, Mohseni S and Mahjoub S, Production of active lipase by Rhizopus oryzae from sugarcane bagasse: solid state fermentation in a tray bioreactor. Int J Food Sci Technol 48:283-289 (2013).

10 Rajagopalan S and Modak JM, Heat and mass transfer simulation studies for solid-state fermentation processes. Chem Eng Sci 49:2187-2193 (1994).

11 Figueroa-Montero A, Esparza-Isunza T, Saucedo-Castañeda G, Huerta-Ochoa S, Gutiérrez-Rojas $\mathrm{M}$ and Favela-Torres $\mathrm{E}$, Improvement of heat removal in solid-state fermentation tray bioreactors by forced air convection. J Chem Technol Biotechnol 86:1321-1331 (2011).

12 Raghavarao KSMS, Ranganathan TV and Karanth NG, Some engineering aspects of solid-state fermentation. Biochem Eng J 13:127-135 (2003). 
13 Belo I, Pinheiro R and Mota M, Fed-batch cultivation of Saccharomyces cerevisiae in a hyperbaric bioreactor. Biotechnol Prog 19:665-671 (2003).

14 Lopes M, Belo I and Mota M, Over-pressurized bioreactors: application to microbial cell cultures. Biotechnol Prog 30:767-775 (2014).

15 Knoll A, Maier B, Tscherrig $\mathrm{H}$ and Büchs J, The oxygen mass transfer, carbon dioxide inhibition, heat removal, and the energy and cost efficiencies of high pressure fermentation. Adv Biochem Eng Biotechnol 92:77-99 (2005).

16 Belo I, Pinheiro R and Mota M, Morphological and physiological changes in Saccharomyces cerevisiae by oxidative stress from hyperbaric air. J Biotechnol 115:397-404 (2005).

17 Lopes M, Gomes N, Gonçalves C, Coelho MAZ, Mota M and Belo I, Yarrowia lipolytica lipase production enhanced by increased air pressure. Lett Appl Microbiol 46:255-260 (2008).

18 Lopes M, Gomes N, Mota M and Belo I, Yarrowia lipolytica growth under increased air pressure: influence on enzyme production. Appl Biochem Biotechnol 159:46-53 (2009).

$19 \mathrm{Xu} \mathrm{FJ}$, Chen $\mathrm{HZ}$ and $\mathrm{Li} \mathrm{ZH}, \mathrm{New}$ developments in engineering aspects of solid-state fermentation. Prog Biotechnol 22:44-48 (2002).

20 Aijun Z, Hongzhang $\mathrm{C}$ and Zuohu L, Air pressure pulsation solid state production of alkaline protease by Bacillus pumilus 1.1625 . Process Biochem 40:1547-1551 (2005).

21 Zeng $\mathrm{W}$ and Chen $\mathrm{HZ}$, Air pressure pulsation solid state fermentation of feruloyl esterase by Aspergillus niger. Bioresource Technol 100:1371-1475 (2009).

22 Chen H-Z, Zhao Z-M and Li H-Q, The effect of gas double-dynamic on mass distribution in solid-state fermentation. Enzyme Microbiol Technol 58-59:14-21 (2014).

23 Zhao H, Zhang $X$ and Li Z, Effects of periodic air pressure oscillation on growth of Rhizobium leguminosarum in a solid state fermenter. Process Biochem 37:165-167 (2001).

24 Canedo MS, de Paula FG, da Silva FA and Vendruscolo F, Protein enrichment of brewery spent grain from Rhizopus oligosporus by solid-state fermentation. Bioprocess Biosyst Eng 39:1105-1113 (2016).

25 Salgado JM, Abrunhosa L, Venâncio A, Domínguez JM and Belo I, Enhancing the bioconversion of winery and olive mill waste mixtures into lignocellulolytic enzymes and animal feed by Aspergillus uvarum using a packed-bed bioreactor. J Agric Food Chem 63:9306-9314 (2015)

26 Serra R, Cabañes FJ, Perrone G, Castellá G, Venâncio A, Mulè G et al., Aspergillus ibericus: a new species of section Nigri isolated from grapes. Mycologia 98:295-306 (2006).

27 Oliveira F, Salgado M, Abrunhosa L, Pérez-Rodríguez N, Domínguez J, Venâncio A et al., Optimization of lipase production by solid-state fermentation of olive pomace: from flask to laboratory-scale packed-bed bioreactor. Bioprocess Biosyst Eng 40:1123-1132 (2017).

28 Oliveira F, Souza CE, Peclat VROL, Salgado JM, Ribeiro BD, Coelho MA et al., Optimization of lipase production by Aspergillus ibericus from oil cakes and its application in esterification reactions. Food Bioprod Process 102:268-277 (2017).

29 Bradford MM, A rapid and sensitive method for the quantitation of microgram quantities of protein utilizing the principle of protein-dye binding. Anal Biochem 72:248-254 (1976).

30 Salgado JM, Abrunhosa L, Venâncio A, Domínguez JM and Belo I, Screening of winery and olive mill wastes for lignocellulolytic enzyme production from Aspergillus species by solid-state fermentation. Biomass Convers Biorefinery 4:201-209 (2014).
31 Leite $P$, Salgado JM, Venâncio A, Domínguez JM and Belo I, Ultrasounds pretreatment of olive pomace to improve xylanase and cellulase production by solid-state fermentation. Bioresource Technol 214:737-46 (2016).

32 Dulf FV, Vodnar DC, Dulf EH and Toşa Ml, Total phenolic contents, antioxidant activities, and lipid fractions from berry pomaces obtained by solid-state fermentation of two Sambucus species with Aspergillus niger. J Agric Food Chem 63:3489-3500 (2015).

33 Sinigaglia M, Di Benedetto N, Bevilacqua A, Corbo MR, Capece A and Romano $P$, Yeasts isolated from olive mill wastewaters from southern Italy: technological characterization and potential use for phenol removal. Appl Microbiol Biotechnol 87:2345-2354 (2010).

34 Tsiamis G, Tzagkaraki G, Chamalaki A, Xypteras N, Andersen G, Vayenas $D$ et al., Olive-mill wastewater bacterial communities display a cultivar specific profile. Curr Microbiol 64:197-203 (2012).

35 Baffi MA, Romo-Sánchez S, Ubeda-Iranzo J and Briones-Pérez Al, Fungi isolated from olive ecosystems and screening of their potential biotechnological use. N Biotechnol 29:451-456 (2012).

36 Pérez-Rodríguez N, Oliveira F, Pérez-Bibbins B, Belo I, Torrado Agrasar $A$ and Domínguez JM, Optimization of xylanase production by filamentous fungi in solid-state fermentation and scale-up to horizontal tube bioreactor. Appl Biochem Biotechnol 173:803-825 (2014).

37 Dundar AN and Gocmen D, Effects of autoclaving temperature and storing time on resistant starch formation and its functional and physicochemical properties. Carbohydr Polym 97:764-771 (2013).

38 Pensupa N, Jin M, Kokolski M, Archer DB and Du C, A solid state fungal fermentation-based strategy for the hydrolysis of wheat straw. Bioresource Technol 149:261-267 (2013).

39 Lonsane BK, Ghildyal NP, Budiatman S and Ramakrishna SV, Engineering aspects of solid state fermentation. Enzyme Microbiol Technol 7:258-265 (1985).

40 Edwinoliver NG, Thirunavukarasu K, Naidu RB, Gowthaman MK, Kambe TN and Kamini NR, Scale up of a novel tri-substrate fermentation for enhanced production of Aspergillus niger lipase for tallow hydrolysis. Bioresource Technol 101:6791-6796 (2010).

41 Ahmed S, Mustafa G, Arshad M and Rajoka MI, Fungal biomass protein production from Trichoderma harzianum using rice polishing. Biomed Res Int 2017:1-9 (2017).

42 Li F, Li F, Zhao T, Mao G, Zou Y, Zheng D et al., Solid-state fermentation of industrial solid wastes from the fruits of milk thistle Silybum marianum for feed quality improvement. Appl Microbiol Biotechnol 97:6725-6737 (2013).

43 García García I, Jiménez Peña PR, Bonilla Venceslada JL, Martín Martín A, Martín Santos MA and Ramos Gómez E, Removal of phenol compounds from olive mill wastewater using Phanerochaete chrysosporium, Aspergillus niger, Aspergillus terreus and Geotrichum candidum. Process Biochem 35:751-758 (2000).

44 Cai $Y$, Luo $Q$, Sun $M$ and Corke $H$, Antioxidant activity and phenolic compounds of 112 traditional Chinese medicinal plants associated with anticancer. Life Sci 74:2157-2184 (2004).

45 AgriAnalysis. Feed and Forage Terminology from Agri Analysis, Inc. 2016. [Online]. Available: http://www.agrianalysis.com/feed-andforage-terminology.shtml [19 October 2016].

46 Joshi VK and Sandhu DK, Preparation and evaluation of an animal feed byproduct produced by solid-state fermentation of apple pomace. Bioresourcce Technol 56:251-255 (1996). 